\title{
THE EFFECT OF POLICY IMPLEMENTATION OF BASIC HEALTH SERVICES DURING THE COVID 19 PANDEMIC
}

(Study of Implementation of Basic Health Services in West Java Province)

\author{
Tati Sarihati, and Pandji Santosa \\ Universitas Langlangbuana Bandung, Indonesia \\ Email: sarihati.tati@gmail.com
}

\begin{abstract}
Facing the Covid 19 pandemic, Indonesia is faced with the quality of essential health services that are still not optimal in various provinces. The main problems of vital health services that have emerged in West Java Province include the number and infrastructure of public health centers, the affordability of services and types of services such as maternal and child health, immunization, nutrition, environmental health and coverage of public health nursing performance. service quality variable, the theoretical approach of Fitzsimmons \& Fitzimmons (2011) is used with Tangibles, Reliability, Responsiveness, Assurance and Empathy factors. The research method used is an informative survey approach by collecting data from library analysis sources and field experiments, including questionnaires, observations, and interviews. The sampling method used is Plain Random Sampling. The selected sample (n) was 92 people. The data analysis methodology used is route analysis. The results of the study reveal the positive and significant impact of policy implementation on the effectiveness of the quality of critical health services. In addition, it was also found that communication effectiveness variables that affect the quality of essential health services in West Java Province are also found
\end{abstract}

Keywords: Policy Implementation; Service Quality; Basic Health.

\section{PENGARUH PENERAPAN KEBIJAKAN KUALITAS PELAYANAN KESEHATAN DASAR PADA PANDEMI COVID19}

(Kajian Pelaksanaan Pelayanan Kesehatan Dasar Di Provinsi Jawa Barat)

\begin{abstract}
ABSTRAK. Menghadapi masa pandemi Covid 19, Indonesia dihadapkan pada kualitas pelayanan kesehatan esensial yang masih kurang optimal di berbagai provinsi. Permasalahan utama pelayanan kesehatan vital yang mengemuka di Provinsi Jawa Barat antara lain jumlah dan infrastruktur puskesmas, keterjangkauan pelayanan dan jenis pelayanan seperti kesehatan ibu dan anak, imunisasi, gizi, kesehatan lingkungan dan cakupan kinerja keperawatan kesehatan masyarakatenelitian menggunakan metode analisis pelaksanaan kebijakan publik, Sedangkan untuk variabel kualitas layanan, pendekatan teoritis Fitzsimmons \& Fitzimmons (2011) digunakan dengan faktor Tangibles, Reliability, Responsiveness, Assurance dan Empathy. Metode penelitian yang digunakan adalah pendekatan survei informatif dengan pengumpulan data sumber analisis kepustakaan dan eksperimen lapangan, meliputi kuesioner, observasi, dan wawancara. Metode pengambilan sampel yang digunakan adalah Plain Random Sampling. Sampel terpilih (n) sebanyak 92 orang. Metodologi analisis data yang digunakan adalah analisis rute. Hasil Penelitian mengungkapkan dampak positif dan penting antara penerapan kebijakan pada efektivitas kualitas layanan kesehatan kritis. Selain itu, ditemukan juga variabel efektifitas komunikasi yang mempengaruhi kualitas pelayanan kesehatan esensial di Provinsi Jawa Barat
\end{abstract}

Kata kunci: Implementasi Kebijakan; Kualitas Pelayanan; Kesehatan Dasar.

\section{INTRODUCTION}

Health programs in Indonesia strive to increase understanding, desire and capacity to live a healthier life for all to realize the highest degree of health as a representation of the general wellbeing as alluded to in our constitution (Andrianto \& Nursikuwagus, 2017; Ulumiyah, 2018; Djasri, 2012). The Health Service is organized based on the National Health System (SKN), which is an agreement that puts together different activities of the Indonesian nation in an organized and mutually beneficial manner to achieve the highest health status (Adisasmito, 2007; Saputra et al., 2015; Putri, 2014). The actors in the implementation of health development are the community and government (central, provincial, district/city). Thus within the government environment, both the Central and Local
Governments must work together synergistically to carry out planned, integrated and sustainable health services to achieve the highest health degree (Suprianto\&Mutiarin, 2017; Mujiati\&Yuniar, 2016; Christasani\&Satibi, 2016).

To improve human resources quality, health development policies are done (Notoatmojo, 2008; Pasaribu, 2015). Health development has a positive relationship with improving the quality of human resources. A high degree of health and nutritional status willincreaseproductivity, whichwillincreasecommunity income or community welfare (Adrianto\&Ningrum, 2010; Utami, 2012; Ramadhanti, 2020). Health Service Policy is one of the main components. The critical role of development as it is now can be seen from its contribution to increasing the productivity of the current generation and the productivity of future health services (Ariati, 2013; Atmarita, 2004) 
Health policy in Indonesia is formulated based on the framework mentioned above, but the implementation mechanism would be affected by the dominant fiscal, political and bureaucratic frameworks (Sumampouw\&Roebijoso, 2017). Therefore, as stated by Walt \& Gilson (1994), the development of health services in a country cannot be separated from the social, economic and political structures that exist in that country, that the system strongly influences the existence of fundamental rights in every citizen in the health sector. The Social, geographic economy of an area is also sufficient to influence the community's needs in getting health services (Smith, 1997). The application of an economic development strategy that tends to be capitalistic, the acceptance of unstable state opinions, the privatization of health and the development of the pharmaceutical industry, which foreign companies dominate, are factors that have a strong influence on people's opportunities to obtain health services. Therefore, these factors will impact community opportunities to get health services (Macinko et al., 2003).

Essential health services are one of the health services that must be administered by local governments (Marniyati et al., 2016). It is operationally worked out from the Community Clinic (Puskesmas) and other primary health service units such as Auxiliary Puskesmas, Medical Center, BKIA, Posyandu, Maternity Clinic, General Practitioner/ Dentist/General Group, Health Laboratory Center, Clinical Laboratory, Pharmacy, Shop Licensed Medicine, Optics and Traditional Medicine. Various research has been carried out on essential health, such as research on Mapping Health Facilities at Puskesmas in South Kalimantan by Latifa Suhada Nisa et al. (2019) and Strategies for Creating Basic Health Services for Ease of Access for Poor Villagers in Gunung Kidul Regency, Central Java Province by Sunyoto Usman et al. (2007) show that fundamental health problems are critical national issues that need to get more in-depth attention from the government.

In West Java Province, there were 1,088 health centres in 2019, consisting of 292 inpatient health centres and 796 non-inpatient health centres. Based on the national requirement that one puskesmas serve a minimum of 25-30 thousand residents. The ratio of population per health centre in West Java from 2015 to 2019 is still above 40,000 . This means that one puskesmas serves 40 thousand people. To achieve the standard of 1 puskesmas to do 30 thousand people, in West Java, 1,623 health centres are needed. This means that West Java still lacks 537 health centres. District/city areas with a ratio of health centres per population close to ideal conditions (1:30,000 people) are found in 3 districts/cities, namely Tasikmalaya City, Bandung City, Kuningan Regency. There are ten city districts with a ratio of health centres to a population more significant than the average of West Java Province 1: 44,829, namely Bekasi Regency, Bekasi City, Depok City, Bandung Regency, Bogor Regency, West Bandung Regency, Cianjur Regency, Purwakarta Regency, Cimahi City and Karawang Regency.

Facing the current pandemic situation, the condition of the types of health services provided by the Puskesmas as the spearhead of essential health services for the community has not shown a favourable condition, if you can see in the table below:

Table 1. Basic Health Services for West Java Province 2018-2019

\begin{tabular}{|c|c|c|c|c|c|}
\hline \multirow[t]{2}{*}{ No } & \multirow[t]{2}{*}{ Type of Service } & \multirow{2}{*}{$\begin{array}{c}\text { Target } \\
(\%)\end{array}$} & \multirow{2}{*}{$\begin{array}{c}\text { Result } \\
(\%)\end{array}$} & \multicolumn{2}{|c|}{$\begin{array}{c}\text { Difference } \\
(\%)\end{array}$} \\
\hline & & & & + & - \\
\hline 1 & $\begin{array}{l}\text { The health of both } \\
\text { mother and child: } \\
\text { - K1 } \\
\text { - K4 } \\
\text { - Delivery of Health } \\
\text { Personnel } \\
\text { - Postpartum Care } \\
\text { - Postpartum mother } \\
\text { gets vitamin a }\end{array}$ & $\begin{array}{l}95 \\
95 \\
90 \\
84 \\
90\end{array}$ & $\begin{array}{l}94.22 \\
87.70 \\
89.87 \\
83.71 \\
89.70\end{array}$ & & $\begin{array}{l}0.78 \\
7.3 \\
0.13 \\
0.29 \\
0.3\end{array}$ \\
\hline 2 & $\begin{array}{l}\text { Immunization: } \\
\text { - BCG } \\
\text { - Diphtheria, Pertussis, } \\
\text { Tetanus (DPT) + HB1 } \\
\text { - Polio } \\
\text { - Measles } \\
\text { - TT 1 } \\
\text { - TT 2+ }\end{array}$ & $\begin{array}{l}96 \\
96 \\
92 \\
92 \\
70 \\
80\end{array}$ & $\begin{array}{l}95.74 \\
95.95 \\
91.82 \\
92.06 \\
69.82 \\
81.26\end{array}$ & $\begin{array}{l}0.06 \\
1.26\end{array}$ & $\begin{array}{l}0.26 \\
0.05 \\
0.18 \\
0.18\end{array}$ \\
\hline 3 & $\begin{array}{l}\text { Nutrition: } \\
\text { a. Overcoming Anemia } \\
\text { - Fe } 1 \text { coverage } \\
\text { - Fe coverage } \\
\text { b. Prevalence of } \\
\quad \text { Malnutrition }\end{array}$ & $\begin{array}{l}91 \\
92\end{array}$ & $\begin{array}{c}94.34 \\
98.80 \\
0.12\end{array}$ & $\begin{array}{l}3.34 \\
6.8 \\
0.12\end{array}$ & \\
\hline 4 & $\begin{array}{l}\text { Environmental Health } \\
\text { - Public and individual } \\
\text { clean water coverage } \\
\text { - Healthy latrine } \\
\text { coverage } \\
\text { - Coverage of household } \\
\text { PHBS }\end{array}$ & $\begin{array}{l}67 \\
71 \\
75\end{array}$ & $\begin{array}{l}67.13 \\
66.48 \\
51.80\end{array}$ & 0.13 & $\begin{array}{l}4.52 \\
23.2\end{array}$ \\
\hline 5 & $\begin{array}{l}\text { Community participation } \\
\text { - Active Alert Village / } \\
\text { RW Coverage } \\
\text { - Purnama and } \\
\text { MandiriPosyandu } \\
\text { - Coverage of People } \\
\text { Dental Health Business } \\
\text { - Elderly health service } \\
\text { coverage }\end{array}$ & $\begin{array}{c}100 \\
64 \\
60 \\
46\end{array}$ & $\begin{array}{c}100 \\
80.90 \\
84.86 \\
26.21\end{array}$ & $\begin{array}{l}20.9 \\
24.86 \\
19.79\end{array}$ & \\
\hline 6 & $\begin{array}{l}\text { Health Service } \\
\text { Coverage } \\
\text { - Outpatient visits at } \\
\text { Puskesmas } \\
\text { - Coverage of Public } \\
\text { Health Nursing } \\
\text { Performance }\end{array}$ & $\begin{array}{l}77 \\
70\end{array}$ & $\begin{array}{l}77.36 \\
44.98\end{array}$ & 0.36 & 35.74 \\
\hline
\end{tabular}

Source: West Java Provincial Health Office, 2019 
With a negative range of each service's percentage of achievement between $0.05 \%$ to $23.2 \%$ in the table above, all types of essential services in West Java Province have not been optimal. Several other indications show that the quality of critical health care is not yet sufficient:

1. Number of health workers at Puskesmas who have not reached the standar.

2. MCH data collection for maternal and child health services still has not surpassed the set target.

3. The collection of data from the Independent Practice Midwives and other health facilities is not optimal;

4. Public awareness and knowledge about the importance of standard prenatal care are still lacking.

5. Has not reached the target service coverage for postpartum visits to have a check-up at the puskesmas

6. Inadequate aspects of service facilities and infrastructure, such as inpatient places. Compared to the total private/individual health service facility, the percentage of each primary health service facility dominates with the amount of $79.59 \%$ compared to the percentage of Puskesmas 4.51\%.

7. Low achievement of Public Health Nursing.

8. Decreased community participation in the implementation of health service programs;

Policy implementation is implementing a program to achieve the goals of Edwards III's policy (Sarihati et al., 2019). According to Edward III, the effectiveness of the policy execution is determined by the efficiency of the coordination variables, the capital, the architecture and the bureaucratic structure as seen in the figure below:

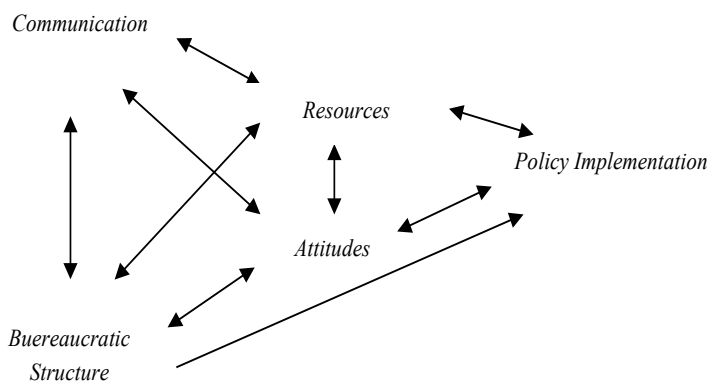

Source: Edwards III

Figure 1 Direct and Indirect Impact of Implementation

Related to the above concept, Edwards III in (Sarihati et al., 2019) states that "Four critical factors or variables in implementing public policy: Communication; resources, dispotions or attitude and bureaucratic structure "that simultaneously interact with each other to help or hinder the implementation of government policies. In the context of public services, Fitzsimmons \& Fitzimmons (2011) state that the quality of the service is complex in order to determine the extent to which the quality of the service can be seen from five dimensions, i.e: Tangibles (touchables) to involve the presence of employees and other physical facilities, such as equipment or equipment supporting services; Reliability, that is, the capacity to deliver the sort of service promised to consumers accurately and correctly; Responsibility, understanding or willingness to support customers and provide swift service; Assurance (guarantee), awareness or insight, politeness, faith on the part of service providers, as well as respect for customers and sympathy (attention) in the form of desire on the part of service providers to approach, offer security and attempt to understand the desires and needs of consumers.

Policy implementation is one of the processes of the public policy cycle. The position of policy implementation is so important in public policy, where the importance of policy implementation is explained by (Wahab, 2005), namely that policy implementation is more important than policy formulation. (Winarno, 2002) explains that public policy implementation is a tool where various actors, organizations, procedures, and techniques work together to carry out policies to achieve the expected goals.

According to (Nugroho, 2004) defines policy implementation as a way for policies to achieve their goals. Both opinions have the same conclusion, namely that policy implementation is a way to achieve what is the goal of a policy. The definition of Winarno explains implementation in more detail by describing the parties involved in implementing the policy, such as organizations, actors (government and non-government) and the systems that are in the implementation of the policy itself.

\section{METHOD}

In this study, the explanatory survey method was used by linking the causality between the studied variables and explaining the causes of the phenomenon occurring in general and universal, as Singarimbun (2008) stated. The data in this study were taken from 2 (two) sources, namely:

1. Primary data sources, namely data obtained directly from the research field, namely from officials and community receiving necessary health services.

2. Secondary Data Sources, namely data obtained from documents, laws and regulations, health service program reports and previous research results relevant to the research object.

To collect data within the framework of using the Explanatory Survey research method, data 
collection techniques refer to the opinion of Neuman (2007), namely:

1. Observation, namely data collection techniques carried out through direct observation in the field of the object's activity being researched, the implementers and officials' behaviour to be interpreted through theoretical parameters.

2. In-depth interviews, through direct questions and answers with respondents and informants. The data obtained were confirmed by cross-checking, especially to the stakeholders involved.

3. Questionnaire/Questionnaire, which is a data collection tool with a list of questions and statements to selected respondents to find out the facts, activities, behaviour and interpretations of respondents and to explore comparative information more fully with alternative answers categorized in the form of numbers following a Likert scale pattern (Mueller, 1986).

The study population was all the West Java Provincial Health Office employees who served either directly or indirectly in basic health services to the community. The population element is 329 people $(\mathrm{N}=329)$. The sampling procedure used was a basic random sampling process. The sample size of this study was 92 participants $(\mathrm{n}=92)$. Data validity was tested using the total item correlation technique and data reliability with Cronbach's internal consistency alpha (Kerlinger, 1986). This research's statistical analysis is a descriptive statistical analysis and path analysis (Riduwan, 2007).

\section{RESULT AND DISCUSSION}

To answer the research objectives, to determine the influence of policy implementation on the quality of essential health services, path analysis techniques are used. For the calculation of the path analysis, the writer used SPSS software. The results of the path coefficient can be presented in the following figure:

$$
\mathrm{R}^{2}=85.6 \%
$$

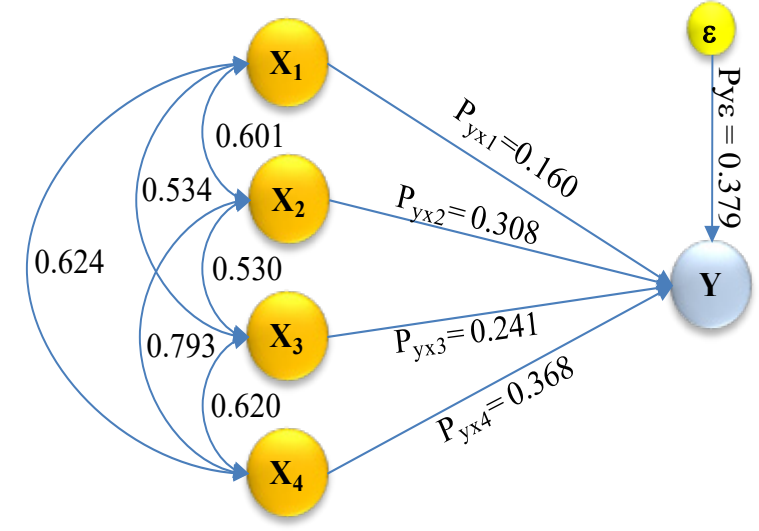

Figure 2. Research Path Diagram with Standardized Coefficient

The Effect of Policy Implementation of Basic Health Services During the Covid 19 Pandemic

(Study of Implementation of Basic Health Services in West Java Province)

(Tati Sarihati, and Pandji Santosa) or written in the following model:

With :

$\mathrm{Y} \quad$ : quality of basic health services

$\mathrm{X}_{1} \quad$ : communication

$\mathrm{X}_{2} \quad$ : resources

$\mathrm{X}_{3} \quad$ : disposition

$\mathrm{X}_{4} \quad$ : bureaucratic structure

The outcome of the estimation of the route coefficient indicates that there is a positive effect on the quality of critical health services in the West Java Province of the policy delivery component, which involves connectivity, finances, disposal and bureaucratic structure. The direction coefficient indicates the direct effect on the endogenous variable of each exogenous variable. The immediate impact of the communication variable on the quality of essential health services is 0.160 . One standard deviation from the resource variable is 0.308 , one standard deviation from the disposition variable is 0.241 , and from the bureaucratic structure variable, 0.368 one standard deviation. Meanwhile, the path coefficient's square explains the diversity or variance of primary health care quality, which the implementation variable can directly explain. This value is sometimes defined as the amount of direct influence resulting from exogenous variables on endogenous variables.

It can be seen that the communication variables explain 0.025 or $2.5 \%$ of the diversity of the primary health service quality variables, the resource variables explain 0.095 or $9.5 \%$ of the variety of the primary health service quality variables, the disposition variables explain 0.058 or $5.8 \%$ the diversity of the primary health service quality variables and the bureaucratic structure variables. Explain 0.136 or $13.6 \%$ of the variability of essential health services' quality through a linear relationship between variables. Meanwhile, the proportion of variance from the variable of crucial health service quality that can be explained simultaneously by the variable of policy implementation is 0.856 or $85.6 \%$. It can be stated that $85.6 \%$ of the variation in the quality of essential health services can be explained by policy implementation.

After estimating the parameters or path coefficients, the next step is to test the path coefficients' significance either simultaneously or partially. The simultaneous model can be described as follows digure 3.

The $\mathrm{F}$ test coefficient is used to test the latter hypothesis. The results of the measurements using the SPSS program obtained a measured $\mathrm{F}$ value of 129,166 with a table $\mathrm{F}$ value of 2,476 . The expected value of $F$ is higher than the value of the table of $F$. It may be inferred that the null hypothesis is dismissed and that the first hypothesis is accepted, which means 
that there is a parallel impact of policy enforcement on the efficiency of basic health care in the province of West Java. The magnitude of the simultaneous impact of policy implementation on the quality of essential health services is a determination coefficient of 0.856 or $85.6 \%$.

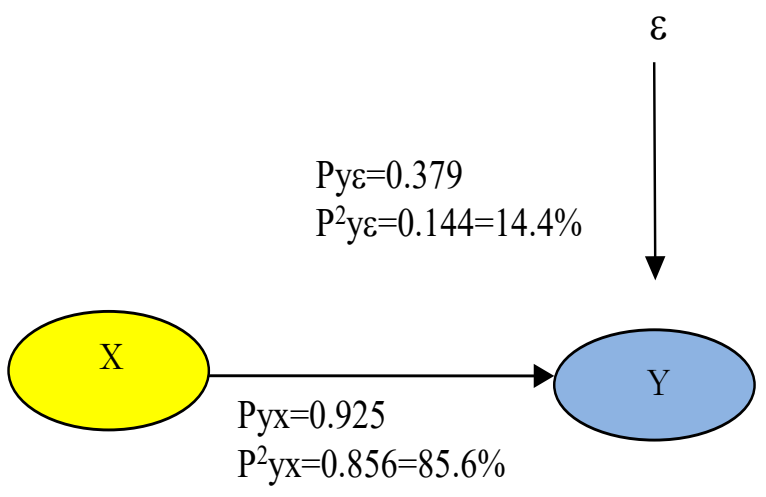

Figure 3. The magnitude of the simultaneous influence of the $\mathrm{X}$ to $\mathrm{Y}$ variables

Partial hypothesis testing was carried out to test whether individually each factor in policy implementation, including communication factors (X1), resource factors (X2), disposition factors (X3) and bureaucratic structure factors (X4), has had a major impact on the delivery of critical health care at the West Java Regional Health Office. The path analysis model can be described as follows:

$$
R^{2}=85.6 \% ; F=129.166
$$

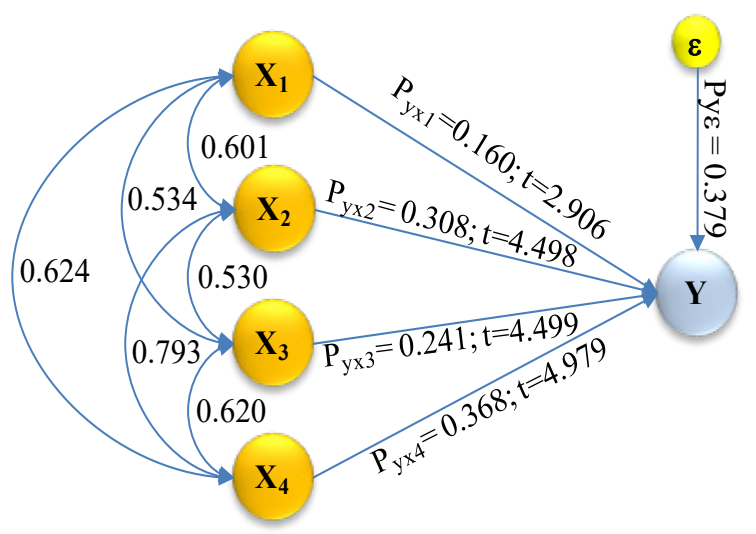

Figure 4. Research Path Diagram with t-student value

The policy implementation variable's simultaneous influence on the quality of essential health services at the West Java Provincial Health Office is the coefficient of multiple determination, namely $\mathrm{R} 2=$ 0.856 or $85.6 \%$. This means that simultaneously $85.6 \%$ of changes in the quality of essential health services are influenced by policy implementation variables, including communication, resources, disposition, and bureaucratic structure factors. Simultaneously, the remaining $14.4 \%$ is influenced by other variables not examined in this study.

The partial effect is the influence of exogenous variables individually on endogenous variables through other exogenous variables.
Table 2. The Influence of Policy Implementation Variables on the Quality of Basic Health Services

\begin{tabular}{lccc}
\hline \multicolumn{1}{c}{ Variable } & Dirrect & Indirrect & Total \\
\hline Communication & 0.025 & 0.087 & 0.112 \\
Resources & 0.095 & 0.159 & 0.254 \\
Disposition & 0.058 & 0.115 & 0.173 \\
Bureaucratic Structure & 0.136 & 0.182 & 0.317 \\
Policy Implementation $=0.856$ & & & \\
\hline
\end{tabular}

Source: 2020 Analysis Results

After calculating the magnitude of the influence, the policy implementation variable's simultaneous impact on the delivery of critical health services at the Western Java Regional Health Office is the coefficient of multiple determination, namely $\mathrm{R} 2=0.856$ or $85.6 \%$. Furthermore, the influence of communication on the quality of essential health services is $11.2 \%$. The effect of resources is $25.4 \%$, the power of the disposition is $17.3 \%$, and the influence of the bureaucratic structure is $31.7 \%$. From these results, it is known that the bureaucratic system gives the most significant impact on policy implementation on the quality of essential health services at the West Java Provincial Health Office. This means that the most dominant factor in improving critical health services is the bureaucratic structure.

The descriptive analysis results show the total score of the communication factor is $73.4 \%$, resources is $69.0 \%$, the disposition is $75.9 \%$, and the bureaucratic structure factor is $66.2 \%$. From the findings of this descriptive analysis, it can be evaluated that, in general, the execution of policies is going well; however, in particular, the bureaucratic systemic element, it is still perceived as low by some respondents. In order to increase the efficiency of critical health care, it is important to improve the bureaucratic system, including factors of clarity of job descriptions and division of labour, clarity of standard operating procedures, and cooperation/ coordination between work units.

In the context of the quality of essential health services, efforts to improve policy implementation will be reflected in the improvements in intangibles, reliability, responsiveness, assurance and empathy factors. The findings of the descriptive study demonstrate that the cumulative score for the observable element is obtained $71.4 \%$, the reliability factor is $66.7 \%$, the responsiveness factor is $74.1 \%$, the assurance factor is $72.3 \%$, and the empathy factor is $72.3 \%$ with a total score for the variable quality of essential health services of $71.1 \%$. In general, the quality of essential health services can be useful, but some factors are still not well perceived by respondents, so it needs to be improved.

The data analysis shows that the communication factor affects essential health services' quality with 
a significant influence of 0.112 or $11.2 \%$. This communication factor consists of good policy information delivery (transmission), clear/unambiguous delivery of policy information (clarity) and consistent delivery of policy information (consistency).

Centered on the outcomes of the data collection and the products of the interviews, it is shown that the communication carried out within the framework of policy implementation has been carried out well, which shows that the total score for the communication factor is $73.4 \%$. This reflects that the delivery of information. Information regarding policy objectives is well stated, clear and detailed. However, the consistency of the delivery of health service information to the broader community needs to be improved, given its positive impact in eliminating the risks that may arise due to delays in primary health services during a pandemic.

Service is basically concerned aspects of life that are very broad, deep government has a state life function to provide the best service to the community, start service in the form of arrangements or services others in order to make ends meet. According to Moenir (2006: 40) "The service concerning the fulfillment of a right, then it becomes an inherent right to follow on everyone". Another definition of service according to Lukman (1999: 6) is "a activities that occur in interactions directly between one person and another or machines physically, and provide customer satisfaction".

From the two opinions above it is understood that service is a process or activities in order to fulfill human needs according to their rights. From the government side, according to Pamudji (1994: 28) that "Public service as activities that aim to fulfill people's need for goods and services ". While Djaenuri (1999: 37) defines community service is "An activity which is embodiment of general government duties regarding the main duties of an agency to be able to serve the needs of the community maximally".

Resource factors affect the quality of essential health services, 0.254 or $25.4 \%$. The resource factor consists of an indicator of the number of implementing officers, the implementing apparatus's authority, and the available supporting facilities. Widodo (2010) states that it will reduce the effectiveness and efficiency of implementing policies without sufficient and adequate equipment. Agustino (2016) argues that resources can include staff/employees or, more precisely, street-level-bureaucrat., information (how to implement policies and compliance of implementers with regulations), authority and facilities needed in implementing procedures that are very important in implementation Policy.

Based on the survey results, the resource factor is still considered low even though the total score is
$69 \%$. The number of implementing officers who are deemed inadequate in terms of quantity and quality is a rising phenomenon. Also, the distribution of the number of employees between sections varies significantly compared to the workload that is the responsibility of each section/division. This situation demonstrates that the division of the number of workers should consider the review of the workload of each segment on the basis of their primary duties and functions, considering that health professionals have a vital role to play in improving the highest level of health care to the population so that people can improve their understanding, desire and capacity to survive. Good enough that the highest quality of wellbeing is realized as an investment in the production of socially and economically efficient human capital and general welfare. In this context, the increase in the number of apparatus and efforts to include/implement training for human resources according to the required competencies gradually and increase health cadres' capacity through coaching, mentoring, and refreshing cadres still cannot answer the increasing service needs of the community.

The data analysis results showed that the disposition factor affected the quality of essential health services, amounting to 0.173 or $17.3 \%$. The disposition factor consists of indicators of understanding of regulations/policies, adherence to procedures and sufficient expertise/abilities of the implementing apparatus.

The survey results provide an overview of the implementation of policies related to disposition factors, with a total score of $75.9 \%$. This reflects that the policy implementation apparatus already has an adequate level of understanding of the regulations/ policies that apply in the implementation of work. Besides, employees' high compliance with policy procedures and placement of employees following their abilities/expertise is beneficial for policy implementation success.

The data analysis results showed that the bureaucratic structure factors affected the quality of essential health services by 0.317 or $31.7 \%$. The bureaucratic structure factors consist of job description indicators/ work division, Standard Operating Procedure (SOP) and cooperation/ coordination between work units.

Overall, the bureaucratic structure factor in policy implementation is still not right, with a total score of only 66.2 in the low category, especially those related to job descriptions and cooperation between parties about policies that are not going well. This shows that collaboration in policy implementation among sections at the West Java Provincial Health Office has not been effective, which implies delays in service delivery. Likewise, the clarity of labour 
division is not following the potential resources possessed by human resources and the facilities that support it. Based on the outcome of the study, the effect of other factors was found to be $14.4 \%$ beyond the variables analyzed.

\section{CONCLUSION}

Simultaneously, the implementation of policies strongly influences the quality of essential health services at the West Java Provincial Health Office. This influence shows that policy implementation can work more effectively through effective communication, quality resources, attitudes in carrying out work, and a responsive bureaucratic structure.

The effect of policy implementation on the quality of essential health services is partially variable. The factor of bureaucratic structure and resources in policy implementation has the most outstanding value. It has a strong influence on the quality of essential health services at the West Java Provincial Health Office. In contrast, the lowest value and not significantly influential are communication and disposition factors. The results also reveal that the quality of essential health services at the West Java Provincial Health Office is not only influenced by the policy implementation variable.

\section{REFERENCES}

Adisasmito, W. (2007). Sistem Kesehatan Nasional. Jakarta: Rajagrafindo Persada.

Adrianto, E.H. \& Ningrum, D.N.A. (2010). Hubungan Antara Tingkat Kesegaran Jasmani Dan Status Gizi Dengan Produktivitas Kerja. KEMAS: Jurnal Kesehatan Masyarakat, 5(2).

Agustino, L. (2016). Dasar-Dasar Kebijakan Publik (Edisi Revisi). Bandung: Alfabeta.

Andrianto, P. \& Nursikuwagus, A. (2017). Sistem Informasi Pelayanan Kesehatan Berbasis Web di Puskesmas. In Seminar Nasional Komputer dan Informatika (p. 6).

Ariati, N.N. (2013). Gizi dan Produktivitas Kerja. Jurnal Skala Husada, 10(2), 214-218.

Atmarita, F. (2004). Analisis Situasi Gizidan Kesehatan Masyarakat. Jakarta: Direktorat Gizi Masyarakat, Departemen Kesehatan.

Christasani, P.D. \& Satibi, S. (2016). Kajian Faktor DemografiTerhadapKepuasanPasienJaminan Kesehatan Nasional Pada Fasilitas Kesehatan Tingkat Pertama. Jurnal Farmasi Sains dan Komunitas (Journal of Pharmaceutical Sciences and Community), 13(1), 28-34.
Decree of the Minister of Health of the Republic of Indonesia Number 828 / Menkes / SK / IX / 2008 concerning Technical Guidelines for Minimum Service Standards in the Health Sector in Districts / Cities

Djasri, A.U.H. (2012).Keselamatan Pasien dan Mutu Pelayanan Kesehatan: Menuju Kemana?. Jurnal Manajemen Pelayanan Kesehatan, 15(04).

Edward III, G. (1984). Implementing Public Policy. New York. JAI Press.

Fitzsimmons, J.A. \& Fitzsimmons, M.J. (2011). Service Management: Operations, Strategy, and Information Technology (p., 4). New York: McGraw-Hill.

Kerlinger, F. N. \& Pedhazur, E.J. (1988). Foundation of Behavioral Research. New York : Holt Rinehard and Wiston.

Law of the Republic of Indonesia Number 23 of 1992 concerning Health.

Law of the Republic of Indonesia Number 25 of 2009 concerning Public Services.

Law of the Republic of Indonesia Number 36 of 2014 concerning Health Workers.

Macinko, J., Starfield, B. \& Shi, L. (2003). The Contribution of Primary Care Systems to Health Outcomes within Organization for Economic Cooperation and Development (OECD) Countries, 1970-1998. Health Services Research, 38(3), 831-865.

Marniyati, L., Saleh, I. \& Soebyakto, B.B. (2016). Pelayanan Antenatal Berkualitas dalam Meningkatkan Deteksi RisikoTinggi pada Ibu Hamil oleh Tenaga Kesehatan di Puskesmas Sako, Sosial, Sei Baung dan Sei Selincah di Kota Palembang. Jurnal Kedokteran dan Kesehatan, 3(1), 355-362.

Mueller, D.J. (1986). Measuring Social Attitudes: A Handbook for Researchers and Practitioners. USA: Teachers College Press

Mujiati, M., \& Yuniar, Y. (2016). Ketersediaan Sumber Daya Manusia Kesehatan pada Fasilitas Kesehatan Tingkat Pertama dalam Era Jaminan Kesehatan Nasional di Delapan Kabupaten-KotadiIndonesia.MediaPenelitian dan Pengembangan Kesehatan, 26(4), 201210.

Neuman, L.W. (2007). Basic of Social Research Qualitative and Quantitative Approaches 2nd Edition University of Wisconsin. WhitewaterUSA: Pearson Education, Inc. 
Nisa, L. S., Siska, D., Noor, G. S. \& Putryanda, Y. (2017). Pemetaan Fasilitas Kesehatan Pada Puskesmas di Kalimantan Selatan. Jurnal Kebijakan Pembangunan, 12(2), 219-229.

Pasaribu, R.M. (2015). Solusi dalam Mengatasi Masalah Pembangunan Kesehatan Masyarakat di Indonesia. Jurnal Ilmiah "DUNIA ILMU”, I(2).

Putri, N. E. (2014). Efektivitas Penerapan Jaminan Kesehatan Nasional Melalui BPJS dalam Pelayanan Kesehatan Masyarakat Miskin di Kota Padang. Tingkap, 10(2), 175-189.

Ramadhanti, A. A. (2020). Status Gizi dan Kelelahan terhadap Produktivitas Kerja. Jurnal Ilmiah Kesehatan Sandi Husada, 11(1), 213-218.

Regulation of the Minister of Health of the Republic of Indonesia Number 741/Menkes/PER/ VII/2008 concerning Minimum Service Standards in the Health Sector in Districts/ Cities.

Saputra,M., Marlinae,L., Rahman,F., \& Rosadi,D. (2015). Program Jaminan Kesehatan Nasional dari Aspek Sumber Daya Manusia Pelaksana Pelayanan Kesehatan. KEMAS: Jurnal Kesehatan Masyarakat, 11(1), 32-42.

Sarihati, T., Rachaju, R.D.K. \& Mukhlisiana, L. (2019). The Policy Implementation Impact on Region Management. International Journal of Recent Technology and Engineering, $8(2$ Special Issue 9), 649-657.

Singarimbun, M. \& Efendi, S. (2008). Metode Penelitian Survei (cetakan kesembilan belas). Jakarta: LP3ES.

Smith, B.C. (1997). The Decentralization of Health Care in Developing Countries: Organizational Options. Public Administration and Development: The International Journal of Management Research and Practice, 17(4), 399-412.
Sumampouw, O.J. \& Roebijoso, J. (2017). Pembangunan Wilayah Berwawasan Kesehatan. Deepublish.

Suprianto, A. \& Mutiarin, D. (2017). Evaluasi Pelaksanaan Jaminan Kesehatan Nasional. Journal of Governance and Public Policy, 4(1), 71107.

Ulumiyah, N.H. (2018). Meningkatkan Mutu Pelayanan Kesehatan dengan Penerapan Upaya Keselamatan Pasien di Puskesmas. Jurnal Administrasi Kesehatan Indonesia, 6(2), 149-155.

Usman, S., Widhyharto, D. S. \& Maika, A. (2010). Strategi Penciptaan Pelayanan Kesehatan Dasar untuk Kemudahan Akses Penduduk Desa Miskin. Jurnal Ilmu Sosial dan Ilmu Politik, 13(3), 306-323.

Usman, S., Widhyharto, D.S., \& Maika, A. (2010). Strategi Penciptaan Pelayanan Kesehatan Dasar untuk Kemudahan Akses Penduduk Desa Miskin. Jurnal Ilmu Sosial dan Ilmu Politik, 13(3), 306-323.

Utami, S.R. (2012). Status Gizi, Kebugaran Jasmani dan Produktivitas Kerja pada Tenaga Kerja Wanita. KEMAS: Jurnal Kesehatan Masyarakat, 8(1), 74-80.

Walt, G. \& Gilson, L. (1994). Reforming the Health Sector in Developing Countries: The Central Role of Policy Analysis. Health Policy And Planning, 9(4), 353-370.

West Java Provincial Health Office. 2020. Health Profile of West Java Province in 2019

Widodo. (2008). Kebijakan Publik, Formulasi, Implementasi dan Evaluasi. Jakarta: PT Elek Media Komputindo. 